\title{
Identification of Indigenous Bacteria Isolated from Shrimp Aquaculture Wastewater with Bioremediation Application: Total Ammoniacal Nitrogen (TAN) and Nitrite Removal \\ (Pengenalpastian Bakteria Asli Dipencilkan daripada Air Sisa Udang Akuakultur dengan Aplikasi Bio Pemulihan: Jumlah Amonia Nitrogen (TAN) dan Penyingkiran Nitrit)
}

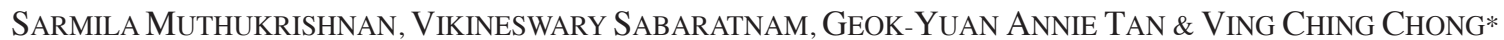

\section{ABSTRACT}

Deterioration of water quality mainly due to high total ammonia nitrogen (TAN) and nitrite will affect the productivity of shrimp culture. In this study, three indigenous strains assigned as VCM5, VCM8 and VCM12 were evaluated for their ability to degrade TAN and nitrite. These strains were inoculated into shrimp aquaculture wastewater to enhance the degradation of TAN and nitrite. All the strains reduced TAN and nitrite level from the shrimp aquaculture wastewater significantly ( $\mathrm{p}<0.05$ ). Strain VCM5 (GenBank accession number KJ700465) and VCM8 (GenBank accession number KJ700464) showed 99.71\% sequence similarity with the 16S rRNA gene type species Bacillus vietnamensis 15-1T (ABO99708) and strain VCM12 (GenBank accession number KJ700463) showed 99.05\% sequence similarity with 16S rRNA gene sequence type species Gordonia bronchialis DSM $43247^{T}$ (CP001802).

Keywords: Bioremediation; shrimp; total ammonia nitrogen

ABSTRAK

Kemerosotan kualiti air terutamanya disebabkan oleh jumlah nitrogen amonia yang tinggi (TAN) dan nitrit akan menjejaskan produktiviti kultur udang. Dalam kajian ini, tiga strain asli dikenali sebagai VCM5, VCM8 dan VCM12 telah dinilai keupayaannya untuk mendegradasi TAN dan nitrit. Strain ini telah diinokulasi ke dalam air sisa udang akuakultur untuk meningkatkan degradasi TAN dan nitrit. Semua strain menurunkan tahap TAN dan nitrit daripada air sisa akuakultur udang dengan ketara $(\mathrm{p}<0.05)$. Strain VCM5 (nombor penerimaan GenBank KJ700465) dan VCM8 (nombor penerimaan GenBank KJ700464) menunjukkan $99.71 \%$ persamaan jujukan dengan spesies jenis gen 16 rRNA Bacillus vietnamensis 15- $1^{T}$ (ABO99708) dan strain VCM12 (nombor penerimaan GenBank KJ700463) menunjukkan persamaan jujukan $99.05 \%$ dengan16 rRNA spesies jenis jujukan gen Gordonia bronchialis DSM43247 ${ }^{T}$ (CP001802).

Kata kunci: Bio pemulihan; jumlah nitrogen amonia; udang

\section{INTRODUCTION}

Indigenous bacteria have an important role in bioremediation. The ability of a microbial population to degrade pollutants in an environment can be increased by stimulating the indigenous microorganisms (El Fantroussi \& Agathos 2005). The role of indigenous bacteria in biodegrading petroleum pollution was first documented by Piehler et al. (1999). Iwabuchi et al. (1998) reported that indigenous bacteria can out-compete artificially introduced strains in several bioremediation investigations. Moreover, bioremediation using artificially introduced strains will have selection pressure resulting in poor remediation and high cell maintenance (Quan et al. 2003). Shan and Obbard (2001) reported that the use of indigenous nitrifying bacteria can reduce inter-specific competition and acclimatisation period. Besides that, periodic change of selected environmental conditions is needed for introduced strains compared with indigenous strains.
The main attraction of using indigenous bacteria in degrading pollutants is its compatibility with the biogeochemical cycle. This approach is sustainable and environmentally 'green' especially during the cleanup processes (El Fantroussi \& Agathos 2005). However, unfavorable environmental conditions and low density of pollutant degrading indigenous bacteria are the drawbacks in bioremediation. Therefore, biostimulation of indigenous bacteria by adding appropriate nutrients usually resulted in satisfactory removal of the target pollutants (Gentry et al. 2004). Biological treatments of aquaculture wastewater are carried out by bacteria that can convert ammonia to nitrate and later, to nitrogen gas. Biological treatment is the most effective way of removing organic wastes. Biological treatment systems rely on mixed microbial cultures to decompose and remove toxic wastes. The treatment compartment holding the microorganisms provides an optimised environment and conditions. For example, the wastewater itself contains the biological food 
and nutrients for the microorganisms. The most frequently asked question is where the 'special' biological cultures are obtained. The answer is that the wide variety of bacteria is found in the waste itself (Hammer \& Hammer 2008).

Both nitrifying and denitrifying bacteria are involved in the biogeochemical nitrogen cycle and control the effluent toxicity of wastewaters (Harms et al. 2003). Nitrification is a microbial process which involves the transformation of ammonia to nitrate. This process is technically feasible and economically favorable (Peng \& Zhu 2006). Denitrification occurs when bacteria use nitrate as terminal electron acceptor in their respiratory process, in the absence of oxygen. Denitrifiers are commonly gram-negative bacteria although some are gram positive. A few halophilic archael microorganisms are also able to denitrify (Cyplik et al. 2007). Recently, both nitrifying and denitrifying bacteria have been used widely in the treatment of industrial wastewater that contains high nitrogenous waste (Foglar et al. 2005). A treatment system that combines nitrification and denitrification seems to be more environmentally-friendly and cost-effective (Paredes et al. 2007). Hence, this study was aimed to identify and characterise the indigenous strains isolated from shrimp aquaculture wastewater based on their TAN and nitrite removal capability.

\section{MATERIALS AND METHODS}

\section{CULTIVATION OF POTENTIAL INDIGENOUS BACTERIA}

The pure cultures (strain VCM5, VCM8 and VCM12) isolated from shrimp wastewater was obtained from the Marine Culture Unit (MCU), University of Malaya. All the cultures were plated onto nitrate agar (SRL, Sisco Research Laboratories Pvt. Ltd, Mumbai India) supplemented with $2 \%(\mathrm{w} / \mathrm{v}) \mathrm{NaCl}$ and incubated at $25 \pm 2^{\circ} \mathrm{C}$ for 4 days.

\section{IN VITRO ASSESSMENTS OF THE STRAINS}

Performances of the strains were further evaluated based on reduction in TAN and nitrite concentrations. Shrimp wastewater effluent was collected from a commercial shrimp farm, JW Shrimp farm, located in Bukit Api-Api, Kuala Selangor, Malaysia. Collection of water samples was done upon harvesting of the shrimps in the ponds. Wastewater was collected in $25 \mathrm{~L}$ plastic carboys and stored under freezing temperature in the laboratory. $100 \mathrm{~mL}$ of bacterial suspension was placed in $2 \mathrm{~L}$ bottle containing $900 \mathrm{~mL}$ of the shrimp wastewater effluent, prepared in triplicates. Every $24 \mathrm{~h}$, water samples were analysed in triplicates for TAN and nitrite concentrations for 5 days. All treatments and control (autoclaved wastewater without any bacteria) was filtered through $0.45 \mu \mathrm{m}$ pore sizes membrane filter before testing for TAN and nitrite.

\section{ANALYTICAL METHODS}

TAN was determined by salicylate method (HACH DR2400 spectrophotometer, USA) with ammonia salicylate reagent, ammonia cyanurate reagent and $\mathrm{AmVer}^{\mathrm{TM}}$ high range ammonia test ' $\mathrm{N}$ tube ${ }^{\mathrm{TM}}$ reagent (HACH, Loveland, USA). Determination of nitrite $\left(\mathrm{NO}_{2}-\mathrm{N}\right)$ based on ferrous sulfate method was carried out using Hach spectrophotometer DR2400, USA.

\section{NITRATE AND NITRITE REDUCTION TESTS}

The resulting bacterial isolates were tested for their ability to produce nitrite by using nitrate reduction test kit (SigmaAldrich Chemie GmbH, Switzerland). $9 \mathrm{~g}$ of nitrate broth powder and nitrite broth powder were dissolved in $1 \mathrm{~L}$ of distilled water in separate flasks. $10 \mathrm{~mL}$ of the broth was dispensed into $20 \mathrm{~mL}$ sample tubes and autoclaved at $121^{\circ} \mathrm{C}$ for $15 \mathrm{~min}$ and cooled. $1 \mathrm{~mL}$ of bacterial sample was then inoculated into three sample tubes. A negative control (uninoculated nitrate and nitrite broth) was set up. All the tubes were incubated at room temperature for 48 h. Five drops of reagent (A) (sulfanilic acid solution) and 5 drops of reagent (B) ( $\alpha$ - naphthylamine solution) were added into all the tubes. The colour changes and air bubbles production in each tube were recorded. If no colour changes in nitrate broth sample tubes occurred, then a small amount of zinc (a toothpick full) was added to each broth. The experiments were repeated for all the strains (Table 1).

\section{BIOCHEMICAL TESTS}

The selected strains were identified to the generic level following standard biochemical test using GenUI MicroPlate $^{\mathrm{TM}}$ (Biolog, Hayward, CA, USA). A 3 mm diameter area of growing cells from the surface of the agar plate was picked using sterile cotton swab. The bacteria was released into the Inoculation Fluid (IF-A) by rubbing the swab tip against the bottom of the tube containing IF-A. Any cell clumps in the IF-A were removed by crushing them against the tube wall. Then, the IF-A was gently tilted upside-down a few times to obtain a uniform cell suspension and the transmittance of cell density ( $\% \mathrm{~T})$ was read using Biolog Turbidimeter (Biolog, Hayward, CA, USA). Then, the GENW Microplates were incubated at $33^{\circ} \mathrm{C}$ in an Omnilog incubator for $24 \mathrm{~h}$. After incubation for 24 or $48 \mathrm{~h}$ in the Omnilog incubator, the resulting patterns were read using the Biolog automated Micro-Station instrument (Biolog, Hayward, CA, USA).

TABLE 1. Experimental design for nitrate and nitrite reduction tests

\begin{tabular}{ll}
\hline & Experiments \\
\hline Control 1 & Nitrate broth + A + B \\
Control 2 & Nitrite broth + A+ B \\
Test 1 & Nitrate broth + A + B + VCM5 \\
Test 2 & Nitrate broth + A + B + VCM8 \\
Test 3 & Nitrate broth + A + B + VCM12 \\
Test 4 & Nitrite broth + A + B + VCM5 \\
Test 5 & Nitrite broth + A + B + VCM8 \\
Test 6 & Nitrite broth + A + B + VCM12 \\
\hline
\end{tabular}




\section{IDENTIFICATION OF SELECTED STRAINS BY GENETIC EVALUATION- 16S rRNA}

DNA was extracted from bacteria suspension after incubating for $24 \mathrm{~h}$ using Nucleospin ${ }^{\circledR}$ Extract II (MACHERY-NAGEL, Germany). The 16SrRnA gene was amplified by PCR machine using universal primer. PCR products were purified with QIAquick PCR purification kit (QIAGEN, USA). Master mixtures for five samples were prepared. The negative control was sterilised distilled water and the positive control was DNA sample which is known to give a product of the correct size. The PCR profile for 16S rDNA amplifications was initial denaturation at $94^{\circ} \mathrm{C}$ for $5 \mathrm{~min}$, followed by 30 cycles of $95^{\circ} \mathrm{C}$ for $1 \mathrm{~min}$, annealing for $45 \mathrm{~s}$ at variable temperature $\left(50-60^{\circ} \mathrm{C}\right.$ ), elongation at $72^{\circ} \mathrm{C}$ for $1 \mathrm{~min}$, a final extension step at $72^{\circ} \mathrm{C}$ for $10 \mathrm{~min}$ and snap cooling at $4^{\circ} \mathrm{C}$. Amplified PCR products were purified using QIAquick PCR purification kit (QIAGEN, USA), following the manufacturers' protocol.

Partial sequencing of the 16SrRNA gene was performed by First Base (Malaysia). The 16SrRnA sequence of the isolate was compared with those of others microorganisms using the Basic Local Alignment Search Tool program (BLAST; htpp://www.ncbi.nlm.nih.gov/BLAST/Blast.cgi) and EzBioCloud server (Kim et al. 2012).

Chromatogram results were analysed and edited using Chromas Lite (Technelysium Pty. Ltd.) software. Subsequent phylogenetic analyses were performed using MEGA 4 (Tamura et al. 2007) software and EzBioCloud server (Kim et al. 2012). Forward and reverse sequences of each gene of each specimen were aligned using ClustalW of Mega 4 to obtain a consensus sequence. A phylogenetic tree was constructed with all successful sequences and was built using Test-Neighbor Joining Tree using 1000 bootstrap replicates.

\section{RESULTS}

PERFORMANCE OF STRAINS BASED ON TAN REMOVAL

Figure 1 shows the performance of selected strains on TAN reduction for 5 days. The control showed insignificant reduction $(p>0.05)$ in the concentration of TAN from day 1 to day 5. Strains VCM5, VCM8 and VCM12 displayed their ability to significantly reduced $(p<0.05)$ the TAN concentration from day 1 to day 5. Strain VCM12 exhibited the highest removal of TAN $(73.80 \%)$ compared to VCM5 $(59.41 \%)$ and VCM8 $(72.25 \%)$ on day 5 . Overall, the TAN concentrations were significantly lower in test treatments when compared with the control (Dunnett's test, $p \leq 0.05$ ).

The highest removal of nitrite was observed for strain VCM12 $(91.61 \%)$ followed by strain VCM5 $(56.24 \%)$ and VCM8 $(53.36 \%)$ on day 5 (Figure 2). However, the overall results showed significant nitrite reduction $(p<0.05)$ as compared with the control.

\section{NITRATE AND NITRITE REDUCTION TESTS}

Nitrate reduction test was carried out to differentiate the ability to reduce nitrate to nitrite or nitrogenous gases. The nitrate reduction test is based on the detection of nitrite and its ability to form a red compound when it reacts with sulfonic acid to form complex nitrite-sulfanilic acid which then reacts with a $\alpha$-naphthylamine to give a red precipitate. If the test organism has reduced the nitrate $\left(\mathrm{NO}_{3}^{-}\right)$to nitrite $\left(\mathrm{NO}_{2}^{-}\right)$, a red colour will appear within 2 min. If no colour changes are observed within $2 \mathrm{~min}$, there are several possibilities: no reduction of nitrate; nitrate $\left(\mathrm{NO}_{3}^{-}\right)$reduced to nitrite $\left(\mathrm{NO}_{2}^{-}\right)$to nitric oxide $(\mathrm{NO})$ or further to nitrous oxide $\left(\mathrm{N}_{2} \mathrm{O}\right)$ or further to nitrogen gas $\left(\mathrm{N}_{2}\right)$; and nitrate reduced directly to molecular nitrogen. However, the addition of zinc (strong reducing agent) to the broth will rapidly reduce $\mathrm{NO}_{3}^{-}$to $\mathrm{NO}_{2}$. Therefore, the appearance of red colour after the addition of zinc to the colourless tube indicates a negative reaction. This signifies the tests organisms are unable to reduced $\mathrm{NO}_{3}^{-}$to $\mathrm{NO}_{2}^{-}$. If the broth remains colourless after the addition of zinc, the test organisms has also reduced $\mathrm{NO}_{2}{ }^{-}$to $\mathrm{N}_{2}$ or other intermediates.

In nitrite reduction test, there will be no colour changes if the $\mathrm{NO}_{2}^{-}$is reduced. Reduction is always confirmed by the presence of air bubbles in the tube or on the surface

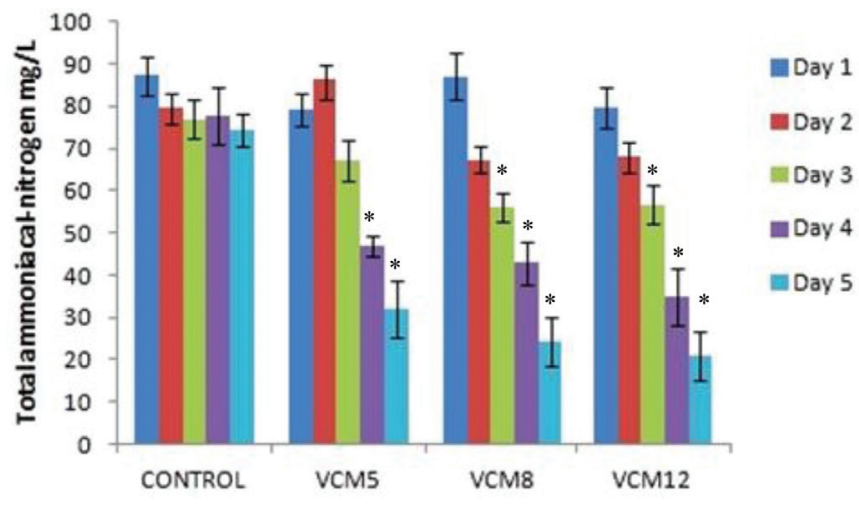

FIGURE 1. Mean total ammoniacal-nitrogen (TAN) reduction by selected strains in shrimp wastewater collected from JW Shrimp farm, Bukit Api-Api, Kuala Selangor, Malaysia over 5 days. Number of replicates $(n)=3$. Vertical lines indicate S.D. The asterisk $(*)$ on the bar means it is significantly different $(p<0.05)$ compared with the control 


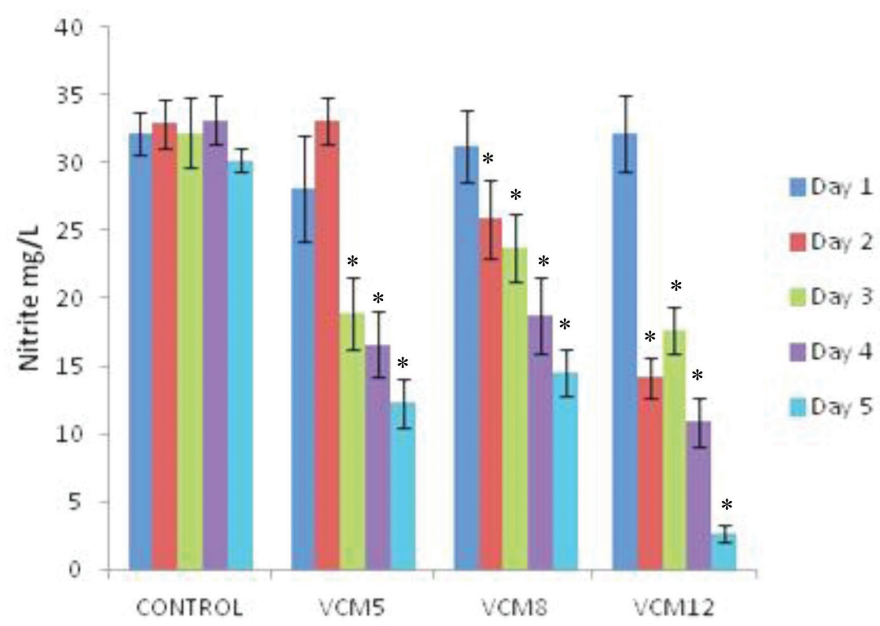

FIGURE 2. Mean nitrite $\left(\mathrm{NO}_{2}^{-}-\mathrm{N}\right)$ reduction by selected strains in shrimp wastewater collected from JW Shrimp farm, Bukit Api-Api, Kuala Selangor, Malaysia over 5 days. Number of replicates $(n)=3$. Vertical lines indicate S.D. The asterisk $(*)$ on the bar means it is significantly different $(p<0.05)$ compared with the control

of the broth indicating $\mathrm{N}_{2}$ gas. If a red colour appears, it indicates the presences of $\mathrm{NO}_{2}{ }^{-}$and hence it is a negative reaction.

There was no colour change in Test 1 (after adding reagent $\mathrm{A}$ and reagent $\mathrm{B}$ ). The broth in test 1 remains colourless after the addition of zinc. Light-pink appearance can be observed in tests 2 and 3. There were no colour changes and presence of air bubbles were observed in tests 4, 5 and 6 (Table 2).

TABLE 2. Nitrate and nitrite reduction tests

\begin{tabular}{ll}
\hline Experiments & Observations \\
\hline Control 1 & No colour changes \\
Control 2 & Red colour changes \\
Test 1 & Light pink \\
Test 2 & Light pink \\
Test 3 & No colour changes \\
& No colour changes after adding zinc dust \\
& Appearance of visible bubbles \\
Test 4 & No colour changes \\
& Appearance of visible bubbles \\
Test 5 & No colour changes \\
& Appearance of visible bubbles \\
Test 6 & No colour changes \\
& Appearance of visible bubbles \\
\hline
\end{tabular}

\section{BIOCHEMICAL ANALYSIS}

Biochemical tests were performed to identify the species. Understanding the characteristics of the selected microorganisms in terms of biochemical, morphological and physiological is very important in order to achieve high efficiency of treatment at all times. All the strains were not resistant to troleandomycin, rifamycin SV, lincomycin, and nalidixic acid (Table 3). Carbon utilization tests (CUS) have been used for the classification and identification of bacteria (Koser 1923). Analysis of the ability of the cells to metabolise all major classes of biochemical, physiological properties and chemical sensitivity were based on GPU MicroPlate ${ }^{\mathrm{TM}}$ categorised. Only selective results were reported here.

\section{MOLECULAR ANALYSIS -16S rRNA}

Phylogeny analysis was performed for strain VCM5, VCM8 and VCM12. Similarity of 16S rRNA gene for strain VCM5 (with $1540 \mathrm{bp}$ ) and strain VCM8 (with 1539) searched in GenBank using BLAST showed $99.71 \%$ sequence similarity with the 16S rRNA gene sequence type species Bacillus vietnamensis $15-1^{\mathrm{T}}$ (AB099708). The 16S rRNA sequence of Jeotgalibacillus salarius ASL-1 ${ }^{\mathrm{T}}$ (EU874389) and Jeotgalibacillus alimentarius YKJ-13 ${ }^{\mathrm{T}}$ (AF281158) were used as an out-group to root the tree. Based on the phylogenetic tree (Figure 3), strain VCM5 and VCM8 is closely related to Bacillus vietnamensis $15-1^{\mathrm{T}}$ (ABO99708) with $63 \%$ bootstrap support.

Strain VCM12 (with 1510 bp) searched in GenBank using BLAST showed $99.05 \%$ sequence similarity with the 16S rRNA gene sequence type species Gordonia bronchialis DSM43247 ${ }^{\mathrm{T}}$ (CP001802). The $16 \mathrm{~S}$ rRNA sequence of Williamsia serinedens IMMIB SR-4 $4^{\mathrm{T}}$ (AM283464) and Williamsia deligens IMMIB RIV-956 ${ }^{\mathrm{T}}$ (AJ920290) were used as an out-group to root the tree. Based on the phylogenetic tree (Figure 4), strain VCM12 is closely related to Gordonia bronchialis $\mathrm{DSM} 43247^{\mathrm{T}}(\mathrm{CP} 001802)$ with $81 \%$ bootstrap support.

\section{DISCUSSION}

Shrimp wastewater was collected from JW Shrimp farm to evaluate the performance of the selected strains on 
TABLE 3. Biochemical, morphological and physiological characteristics of strain VCM5, VCM8 and VCM12

\begin{tabular}{|c|c|c|c|}
\hline Characteristics & VCM5 & VCM8 & VCM12 \\
\hline $\begin{array}{l}\text { Colony colour } \\
\text { Colony texture } \\
\text { Gram's staining }\end{array}$ & $\begin{array}{l}\text { whitish-pink } \\
\text { smooth } \\
\text { negative }\end{array}$ & $\begin{array}{l}\text { whitish-pink } \\
\text { smooth } \\
\text { negative }\end{array}$ & $\begin{array}{l}\text { red-pinkish } \\
\text { smooth } \\
\text { positive }\end{array}$ \\
\hline Growth at: $\begin{aligned} & 37^{\circ} \mathrm{C} \\
& 47^{\circ} \mathrm{C}\end{aligned}$ & $\begin{array}{l}+ \\
-\end{array}$ & $\begin{array}{l}+ \\
-\end{array}$ & $\begin{array}{l}+ \\
-\end{array}$ \\
\hline $\begin{array}{c}\mathrm{NaCl} \text { tolerance }(\mathrm{w} / \mathrm{v}): \\
4 \% \\
8 \% \\
12 \%\end{array}$ & $\begin{array}{l}+ \\
+ \\
-\end{array}$ & $\begin{array}{l}+ \\
+ \\
\mathrm{w}\end{array}$ & $\begin{array}{l}+ \\
+ \\
+\end{array}$ \\
\hline $\begin{array}{l}\text { Nitrate reduction } \\
\text { Oxidase test } \\
\text { Catalase test }\end{array}$ & $\begin{array}{c}+ \\
\text { nd } \\
\text { nd }\end{array}$ & $\begin{array}{l}+ \\
\text { nd } \\
\text { nd }\end{array}$ & $\begin{array}{l}+ \\
- \\
+\end{array}$ \\
\hline \multicolumn{4}{|l|}{ Utilisation of: } \\
\hline $\begin{array}{l}\text { D-Maltose } \\
\text { D-Trehalose } \\
\text { Sucrose } \\
\text { D-Raffinose } \\
\alpha \text { - D-Lactose } \\
\text { D-Melibiose } \\
\alpha \text { - D-Glucose } \\
\text { D-Mannose } \\
\text { D-Fructose } \\
\text { D-Galactose } \\
\text { L-Rhamnose } \\
\text { Inosine } \\
\text { D-Sorbitol } \\
\text { D-Mannitol } \\
\text { Glycerol }\end{array}$ & $\begin{array}{l}+ \\
+ \\
+ \\
+ \\
+ \\
+ \\
+ \\
+ \\
+ \\
+ \\
+ \\
+ \\
+ \\
- \\
+\end{array}$ & $\begin{array}{c}- \\
- \\
+ \\
\mathrm{V}^{(-)} \\
+ \\
- \\
+ \\
+ \\
\mathrm{V}^{(+)} \\
\mathrm{V}^{(+)} \\
- \\
+ \\
+ \\
- \\
+\end{array}$ & $\begin{array}{l}+ \\
- \\
+ \\
+ \\
+ \\
+ \\
+ \\
+ \\
+ \\
- \\
- \\
+ \\
+ \\
+ \\
+\end{array}$ \\
\hline \multicolumn{4}{|c|}{ Antibiotic resistance test: } \\
\hline $\begin{array}{l}\text { Troleandomycin } \\
\text { Rifamycin SV } \\
\text { Lincomycin } \\
\text { Lincomycin } \\
\text { Vancomycin }\end{array}$ & $\begin{array}{l}- \\
- \\
- \\
-\end{array}$ & $\begin{array}{l}- \\
- \\
- \\
-\end{array}$ & $\begin{array}{l}- \\
- \\
- \\
- \\
-\end{array}$ \\
\hline
\end{tabular}

Symbols and Abbreviations: +, positive; -, negative; $\mathrm{V}^{(-)}$, variable with most negative; $\mathrm{V}^{(+)}$, variable with most positive, nd, not determined

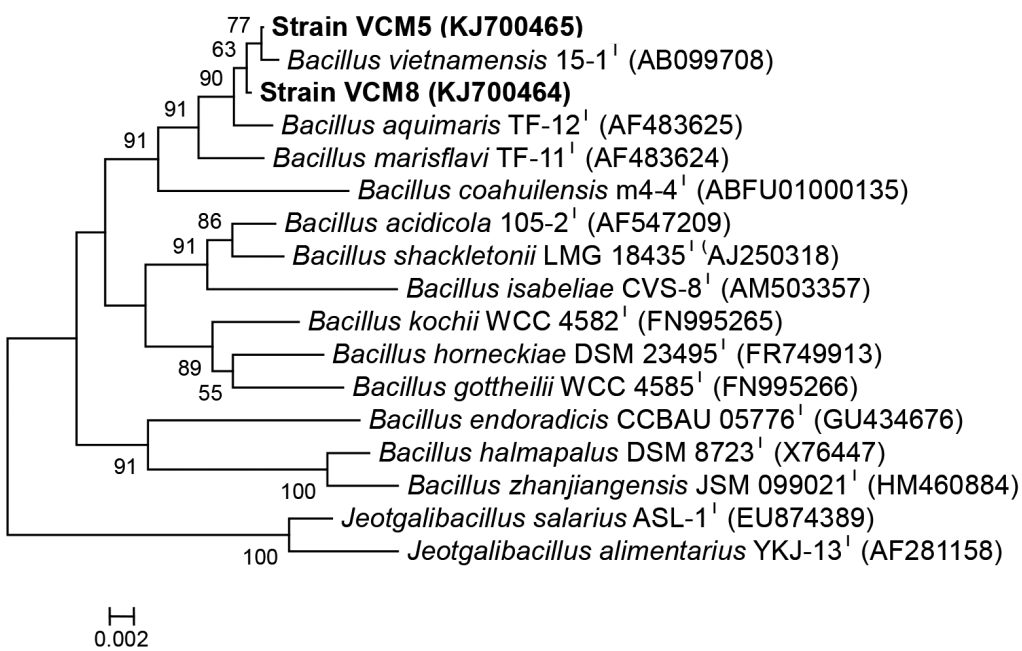

FIGURE 3. Phylogenetic position of strain VCM5 and VCM8 within the genus Bacillus based on 16S rRNA gene sequences. The tree was constructed using the neighbour-joining method. The numbers at the branching points are the percentages of occurrence in 1000 bootstrapped trees. The bar indicates a distance of 0.002 substitutions per site 


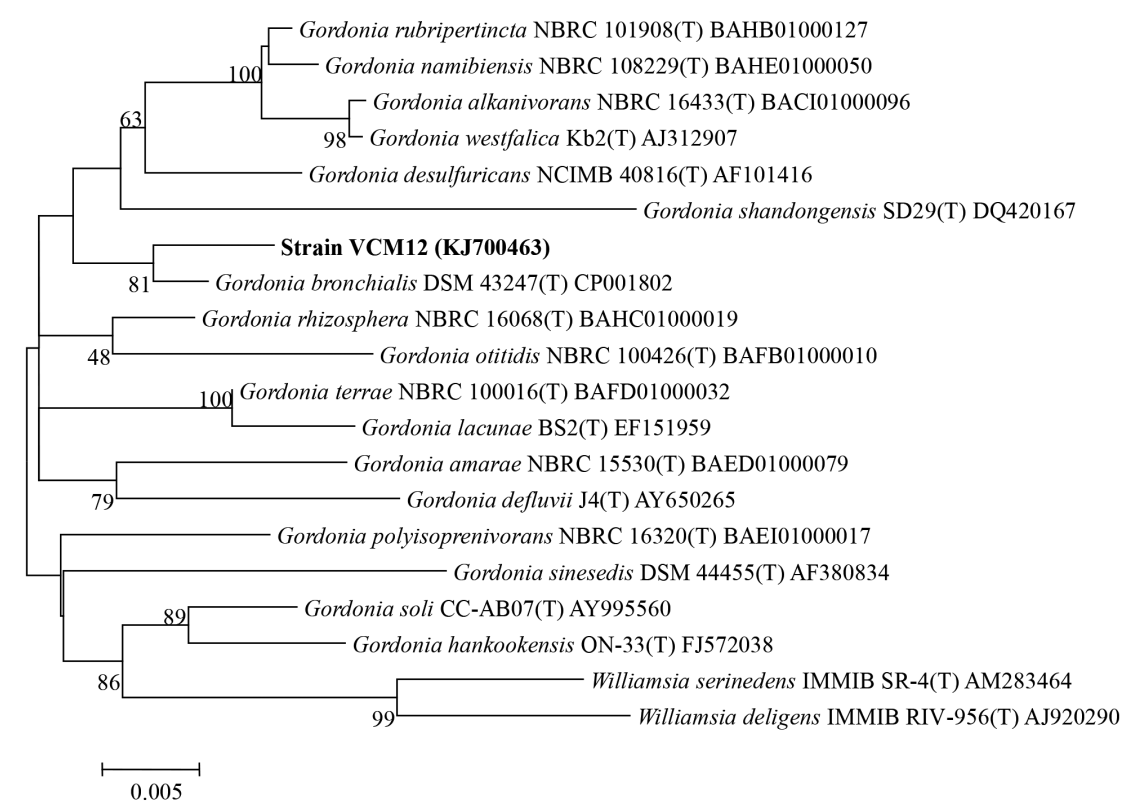

FIGURE 4. Phylogenetic position of strain VCM12 within the genus Gordonia based on 16S rRNA gene sequences.

The tree was constructed using the neighbour-joining method. The numbers at the branching points are the percentages of occurrence in 1000 boot strapped trees. The bar indicates a distance of 0.005 substitutions per site

nitrogenous rich wastewater. For example, the TAN concentration of the shrimp wastewater collected from JW Shrimp farm ranged from 79.13 to $87.19 \mathrm{mg} / \mathrm{L}$ on Day 1 which was extreamly high and lethal to the aquatic organisms. High stocking density of shrimps in the farm due to increasing world market demand resulted in heavy waste loads from culture ponds from uneaten feed and metabolic wastes (Lin 1995). Increasing metabolic wastes and uneaten feed contribute to nitrogenous wastes. Therefore, the wastewater from the farm was used to evaluate the performance of the selected strains to reduce TAN and nitrite efficiently in a shorter period of time.

The application of bacteria as biological agents for improving water quality is widely used and sold worldwide. Bacillus spp. has been widely used in bioremediation of wastewater (Chen et al. 2013; Kim et al. 2005). For instance, 'B3 (Bio Best Bacillus) process' (Korean Patent No.151928) has been well known as advanced wastewater treatment system. Bacillus strains were predominantly used in this system for the wastewater treatment (Kim et al. 2005). Moreover, the study shows that simultaneous nitrification and denitrification, i.e. the partial nitrification of ammonia to nitrite and subsequently continues with direct reduction of nitrite to nitrogen gas capable of removing industrial nitrogenous waste effectively (Morita et al. 2008). It is interesting to report strains with dual function; nitrification and denitrification. Similarly, Kim et al. (2005) reported that a few Bacillus strains were capable to perform simultaneous aerobic nitrification and denitrification. Yang et al. (2011) proved that Bacillus subtilis, strain A1 is capable of converting ammonium directly to gaseous nitrogen compound under aerobic conditions. In this study, strain VCM5 and VCM8 which were identified as Bacillus sp. also showed similar conversion. Both the strains were capable of reducing TAN and nitrite based on the in vitro assessment. Additionally, both the strains showed positive results in nitrate reduction test and nitrite reduction test.

Strain VCM12 was capable of reducing TAN, nitrite and nitrate based on in vitro assessment, nitrate and nitrite reduction tests. Strain VCM12 belongs to the genus Gordonia which is well-known in bioremediation (Chen et al. 2012; Kāmpfer et al. 2012). Strain VCM12 showed significant reduction of TAN and nitrite removal compared to strain VCM5 and VCM8. This fact suggests that strain VCM12 was involved in active nitrification (to remove TAN) and denitrification (conversion of nitrate to $\mathrm{N}_{2}$ gaseous) compared to strain VCM5 and VCM8. The diagram shows the simplified nitrogen pathway from this study (Figure 5).

Therefore, strain VCM5, VCM 8 and VCM12 are capable of converting TAN to $\mathrm{NO}_{2}^{-}$and further to $\mathrm{NO}_{3}{ }^{-}$and $\mathrm{N}_{2}$. These strains play a vital role in nitrogen metabolisms. The most preferred pathway in aquaculture wastewater bioremediation is the TAN and $\mathrm{NO}_{2}^{-}$assimilation by the bacteria since these nitrogenous components are toxic to aquatic organisms.

\section{CONCLUSION}

To date, only a very small percentage of study on indigenous isolates from shrimp wastewater for TAN and nitrite reduction is done. With the current vast development in microbial biotechnology, this study can help as a part in the discovery of potential useful products from indigenous microorganisms. The results from this study provide some useful information that indigenous bacteria from the genus 


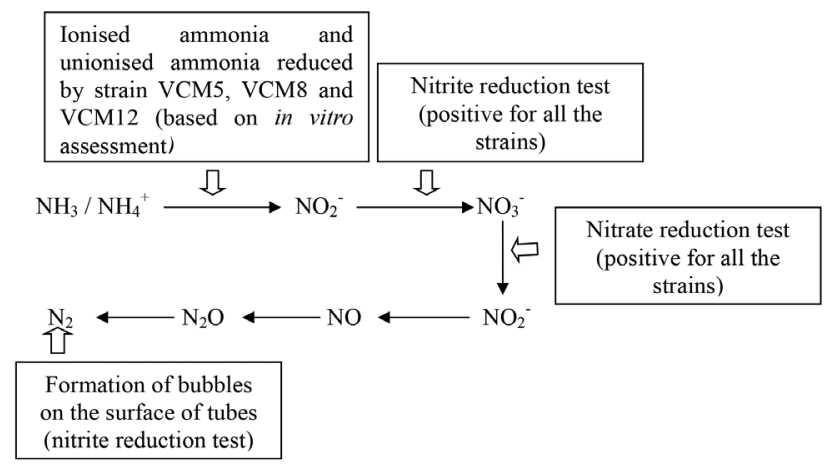

FIGURE 5. The schematic diagram of TAN, nitrite and nitrate assimilation in this study by strain VCM5, VCM8 and VCM12

Bacillus and Gordonia are capable of improving water quality through assimilation of TAN and nitrite.

\section{ACKNOWLEDGEMENTS}

This work was supported by the research Grant PPP2012 from University of Malaya, (PV007/2012A) and Ministry of Science, Technology and Innovation (MOSTI) Science Fund (53-02-03-1024).

\section{REFERENCES}

Chen, K., Yang, J. \& Zhao, H. 2013. Isolation and characterization of Bacillus strain for alkaline wastewater treatment. African Journal of Microbiology Research 7: 5119-5125.

Chen, J., Zhan, P., Koopman, B., Fang, G. \& Shi, Y. 2012. Bioaugmentation with Gordonia strain JW8 in treatment of pulp and paper wastewater. Clean Technologies and Environmental Policy 14: 899-904.

Cyplik, P., Grajek, W., Marecik, R., Kroliczak, P.\& Dembczynski, R. 2007. Application of membrane bioreactor to denitrification of brine. Desalination 207: 134-143.

El Fantroussi, S. \& Agathos, S.N. 2005. Is bioaugmentation a feasible strategy for pollutant removal and site remediation? Current Opinion in Microbiology 8: 268-275.

Foglar, L., Briŝki, F., Sipos, L. \& Vuković, M. 2005. High nitrate removal from synthetic wastewater with the mixed bacterial culture. Bioresource Technology 96: 879-888.

Gentry, T.G., Rensing, C. \& Pepper, I.L. 2004. New approaches for bioaugmentation as a remediation technology. Critical Reviews on Environmental Sciences and Technology 34: 447-494.

Hammer, M.J. \& Hammer, M.J.J. 2008. Water and Wastewater Technology. New Jersey: Pearson Prentice Hall.

Harms, G., Layton, A.C., Dionisi, H.M., Gregory, I.R., Garrett, V.M., Hawkins, S.A., Robinson, K.G. \& Sayler, G.S. 2003. Real time PCR quantification of nitrifying bacteria in a municipal wastewater treatment plant. Environmental Science and Technology 37: 343-351.

Iwabuchi, T., Yamauchi, Y.I., Katsuta, A. \& Harayama, S. 1998. Isolation and characterization of marine Nocardioides capable of growing and degrading phenanthrene at $42^{\circ} \mathrm{C}$. Journal of Marine Biotechnology 6: 86-90.

Kāmpfer, P., Martin, K. \& Dott, W. 2012. Gordonia phosphorivorans sp. nov., isolated from a wastewater bioreactor with phosphorus removal. International Journal of Systematic and Evolutionary Microbiology 63: 230-235.

Kim, J.K., Park, K.J., Cho, K.S., Nam, S.W.,Park, T.J. \& Bajpai, R. 2005. Aerobic nitrification-denitrification by heterotrophic Bacillus strains. Bioresource Technology 96: 1897-1906.

Kim, O.S., Cho, Y.J., Lee, K., Yoon, S.H., Kim, M., Na, H., Park, S.C., Jeon, Y.S., Lee, J.H., Yi, H., Won, S. \& Chun, J. 2012. Introducing EzTaxon-e: A prokaryotic 16S rRNA Gene sequence database with phylotypes that represent uncultured species. International Journal of Systematic and Evolutionary Microbiology 62: 716-721.

Koser, S.A. 1923. Utilization of the salts and organic acids by the colon-aerogenes group. Journal of Bacteriology 8: 493-520.

Lin, C.K. 1995. Progression of intensive marine shrimp culture in Thailand. In Swimming through Troubled Water. Proceedings of the Special Session on Shrimp Farming, Aquaculture '95, edited by Browdy, C.L. \& Hopkins, J.S. Baton Rouge: World Aquaculture Society. pp. 13-23.

Morita, M., Uemoto, H. \& Watanabe, A. 2008. Nitrogenremoval bioreactor capable of simultaneous nitrification and denitrification for application to industrial wastewater treatment. Biochemical Engineering Journal 41: 59-66.

Paredes, D., Kuschk, P., Mbwette, T., Stange, F., Müller, R. \& Köser, H. 2007. New aspects of microbial nitrogen transformations in the context of wastewater treatment - A review. Engineering in Life Sciences 7(1): 13-25.

Peng, Y. \& Zhu, G. 2006. Biological nitrogen removal with nitrification and denitrification via nitrite pathway. Applied Microbiology and Biotechnology 73(1): 15-26.

Piehler, J., Brecht, A., Hehl, K. \& Gauglitz, G. 1999. Protein interactions in covalently attached dextran layers. Colloids and Surfaces B: Biointerfaces 13: 325-336.

Quan, X.C., Shi, H.C., Wang, J.L. \& Qian, Y. 2003. Effects of phenol presence on the biodegradation of 2,4-dichlorophenol in a bioaugmentation system. Huan Jing Ke Xue 24: 75-79.

Shan, H. \& Obbard, J.P. 2001. Ammonia removal from prawn aquaculture water using immobilized nitrifying bacteria. Applied Microbiology and Biotechnology 57(5-6): 791-798.

Tamura, K., Dudley, J., Nei, M. \& Kumar, S. 2007. MEGA4: Molecular evolutionary genetic analysis (MEGA) software version 4.0. Molecular Biology and Evolution 24: 1596-1599.

Yang, X.P., Wang, S.M., Zhang, D.W. \& Zhou, L.X. 2011. Bioresource technology isolation and nitrogen removal characteristics of an aerobic heterotrophic nitrifying denitrifying bacterium, Bacillus subtilis A1. Bioresource Technology 102(2): 854-862. 
Sarmila Muthukrishnan, Vikineswary Sabaratnam, Geok-Yuan Annie Tan \& Ving Ching Chong* Institute of Biological Sciences, Faculty of Science University of Malaya, 50603 Kuala Lumpur Malaysia

Vikineswary Sabaratnam \& Geok-Yuan Annie Tan Mushroom Research Centre, Institute Biological Sciences Faculty of Science, University of Malaya 50603 Kuala Lumpur Malaysia
Sarmila Muthukrishnan, Geok-Yuan Annie Tan \& Ving Ching Chong*

Institute of Ocean and Earth Sciences (IOES)

University of Malaya, 50603 Kuala Lumpur Malaysia

*Corresponding author; email: chong@um.edu.my

Received: 10 August 2014

Accepted: 24 March 2015 